\title{
HUMAN RIGHTS IN THE PERSPECTIVE OF ADAT LAW
}

\author{
Sepranadja \\ Universitas Bhakti Kencana Bandung \\ sepranadja@gmail.com
}

\begin{abstract}
The establishment of Law Number 26 of 2000 concerning Human Rights Courts aims to address human rights violations in Indonesia in order to protect human rights. However, in practice the handling of human rights violations always leads to differences in views between human rights enforcement agencies / apparatuses, either the National Commission on Human Rights, the Public Prosecutor, and the authorized institutions in addressing human rights violations that occur in Indonesia, which can be seen from the process of rolling several cases of human rights violations from the process of investigation. Human rights violations related to crimes against humanity in Indonesia occurred in several areas, including cases of land acquisition of peasants and the relocation of residents of Ankola, Cianjur, West Java since 1984-until now have not yet been resolved. This is because the limitations of formal law as a means of resolving and handling the problem of human rights violations under the non-gross category through a non-judicial approach or out of court settlement. Based on these problems, a descriptive analytical study was conducted using a normative juridical approach that is testing and reviewing secondary data with the stage of library research and field studies, then the data were analyzed with qualitative juridical analysis. The findings showed that the concept in handling human rights violations under the principle of justice through the criminal justice system in Indonesia is carried out through an integrated criminal justice system. Whereas in order to integrate the criminal justice system, one of them is by giving full authority to the National Human Rights Commission to handle cases of human rights violations at the stage of investigation, inquiry and prosecution.
\end{abstract}

Keywords: Human Rights Violations, Criminal Justice System, Justice.

\section{Introduction}

Indonesia recognizes and upholds Human Rights issues and human basic freedom as the basic rights that is attached to and inseparable from man, to be protected, respected and upheld to improve the dignity, welfare, happiness, and intelligence as well as justice as stipulated in Article 2 of Law Number 39, 1999 concerning Human Rights. Indonesia recognizes and upholds human rights and human basic freedom as the rights naturally attached to and inseparable with man to be protected, respected, and secured for the improvement of human dignity, welfare, happiness, and intelligence and justice.[1]

The efforts to protect and uphold human rights should not be taken for granted, but it needs a long process, at least 3 (three) main variables: international dynamics, legal instruments, and how to determine historical approach.[2]
Demand to address cases of human rights violation occurred in Indonesia such as in Aceh, in Timor-Timur pre and post 1999 referendum, in Tanjung Priok on 12 September 1984, case of the raid on Indonesia Democratic Party headquarters (known as case 27 July 1996), case of abduction of activist (1998), and case of Angkola farmet at South Cianjur (1982-1996). National Comission of Human Rights in its annual report reported that government should settle any forms of crime against human rights occurred previously in this land.

The handling of Tanjung Priok, Military Operation Area of Aceh, Papua and case of gross violation of human righs in Timor-Timur pre and post referendum was deemed unsuccessful. In fact, it was the ground for United Nations Security Council to enact Resolution No. 1264, 1999 criticizing the gross violation against human rights occurred in Indonesia at that time. 
Accordingly, UN Security Council demanded for the perpetrators of gross violation against human rights to be accountable for their action before the court (Article 25 jo. Article 2 (6) jo Article 49 of UN Charter. In this case, international criminal court was demanded to be established due to theuntrust from the international world against Indonesian justice system. One of the reasons for this untrust was the allegation that the unsubs were state apparatus, for example in Timor-Timur, the crime against humanity was facilitated by the government agents therefore it would be more difficult to put those agents on trial fairly and impairtially.

Upon the resolution, Indonesia strictly rejected the idea and stated that it would address the case under national mechanism since Indonesian Constitution has covered the provision to try crime against humanity in its court. This rejection brought a consequence that Indonesia should serve justice upon the crime against humanity in Indonesia.

The demand to resolve human rights violation in Indonesia is legal problem that cannot be held or avoided to upright justice and to secure the existence as law state. The state commitment to prosecute and to bring the perpetrator of human rights violation to justice through the establishment of Human Rights Court became urgent and strategic. The resolution taken by Indonesia with the ratification various international legal instruments is the evidence of government political will in uphold human rights in general and of law enforcement against the violation of human rights at crimes against humanity category.[3]

Substantially, Law Number 26, 2000 only adopted the norms in Rome Statute of International Criminal Court. However, the adoption was not complete with so many errors that raised interpretations in its employment. With no procedure law and certain evidence in this crime against humanity is also one of the weaknesses of Law Number 26, 2000. In fact, there are major 8 international human rights laws enacted in Indonesia and should have been the referrence, however in reality, they are not yet if not. This development, basically should be seen as the amendment of the Law Number 26, 2000.[4]

Procedurally and institutionally Human Rights Court Act is, actually, deemed weak. One of which is the power to investigate, inquiry, and prosecute that lay under two different institution: National Commission of Human Rights and General Attorney Office. Moreover, the promulgation of law concerning the Protection of Victims and Witnesses (hereinafter called LPSK) which relation and mechanism are not covered in this law. In fact, as generally known, the greatest power of LPSK is on its endeavor to provide protection including restitution and compensation for the victims of human rights violation.

That Indonesia was slow in addressing issues of human rights violation raised questions on what are the factors generating National Commission on Human Rights, Police Force, Attorney Office, and Court as the law enforcement in handling cases of violation of human rights to be weak and powerless so that the State was not able to guard and protect human rights? Violation of human rights regarding crimes against humanity occurs in some part of Indonesia, one of which is the incursion of farmer's lands and the resettlement of Ankola community in Cianjur, West Java since 1984 up to now that has not yet resolved. It is because the limitation of formal law as the medium to solve and handle cases of the non-gross violation against human rights through non-judicial approach or out-of-court settlement.

The settlement of human rights violation always generated dissenting opinion inter-institutions/law enforcement of human rights both National Commission of Human Rights, Prosecutor, and authorized institutions in addressing human rights violation in Indonesia seen from some cases processed in court. Often, the resolution and settlement of human rights violation with minor category was conducted with a non-judicial approach or out-of-court settlement.

To apply regulations in the Code of Procedure, related law enforcement agencies are necessary of which follows the functional differentiation and coordination principles. Both principles aim to realize the integrated criminal justice system. [5]

Integrated criminal justice system known as criminal justice system or enforcement of justice system in criminal justice system[6]. This system is about criminal justice procedure whose scope is related to the mechanism of criminal court. All 
criminal justice institution are responsible to handle or control human rights violations.

Starting from the above mentioned, author was interested in conducting research titled: "Human Rights in The Perspective of Hukum Adat". This research focused on the study on the use of formal legal instrument in addressing human rights violation in the theoretical frame of integrated criminal justice system, and focused also on the analysis on the application of positive legal principles and norms in handling the issue of human rights violations in Indonesia. Based on the background above, the problems can be formulated as: 1) How is the human rights violation addressed and handled in the perspective of Indonesian criminal justice system?; 2) What is the concept in handling the human rights violations under the principle of justice in Indonesian criminal justice system?

\section{Method}

Method used in this research was juridical normative approach that examines and studies the secondary data. Regarding the juridical normative approach used, the research done was in two stages i.e. library study and supporting field research. Data analysis used was juridical qualitative in which the data obtained, secondary and primary data, were analyzed without statistical formulation.

\section{Result and Discussion}

a. Addressing and Handling of Human Rights Violation in the Perspective of Indonesian Criminal Justice System

Justice system is case-handling system since the claim filed by a party harmed or since the allegation of a person committing criminal offense to the execution of court decision. Specifically for the criminal justice system as a network, criminal justice system operates criminal law as the main operatives, in this case, are material criminal law, formal criminal law, and criminal procedure law [7]

In its development the "Criminal Justice system" is now becoming the term referred to work of mechanism in overcoming the crime on the basis of system approach since in criminal justice system, there are institutions whose power and duty are based on laws applied where one institution is related to others in execution of criminal justice in handling criminal cases. This criminal justice process is started with process of apprehension, detainment, prosecution, and court hearing, and ended with the execution of court decision at correctional service.

Criminal justice system in Indonesia is referring more to due process model which, as we know, that Indonesian criminal justice system is to solve a crime case by stressing on all facts found in a case obtained through stages of formal procedure such investigation, inquiry, prosecution, court proceeding, and the execution of court decision that all is stipulated in the Code of Criminal Procedure.

Muladi argued that due process model is extremely suitable with Indonesia since this model referring to daad-dader strafrecht known as interest-balanced mode concerning various interests to be protected by the criminal law i.e. the interest of the State, public interest, invidiual interest, the interest of criminal offender and the interest of the crime victims.[8] (Romli Atmasasmita: 1996,14)

The handling of human rights violation in Indonesia is under the due process model, certainly this model applies at the court system addressing the violation of human rights. In the handling mechanism of human rights violation, Court of Human Rights is recognize as rechtbank and the court system is the rechtspraak.

In handling violations of human rights in Indonesia, the violation is put into the categories. Under positive law the violation falls into two categories: minor or medium and gross violation of human rights. To distinguish the two categories, we can view how the positive law stipulates each.

For the gross violation of human rights, it is explicitly stipulated in the Law Number 26, 2000 concerning Human Rights Court. The law defines gross violation of human rights as extraordinary crimes and vastly impacts the national and international level and is not the crimes stipulated in the Penal Code. There are two types of crime regulated in the Law Number 26, 2000 i.e. the crime of genocide and crime against humanity. These two crimes in international instruments are recognized as parts of the most serious crimes. These crimes are derived from crimes formulated in Rome Statute 1998. 
Under Article 8 of Law Number 26 , 2000 , the crime of genocide is defined as any actions committed with intention to destroy or annihilate in whole or in part of a nation, race, ethnic group, religious group by:

1) Killing members of group;

2) Causing serious bodily or mental harm to members of the group;

3) Deliberately inflicting on the group conditions of life calculated to bring about its physical destruction;

4) Imposing measures to prevent birth within the groups;

5) Forcibly transferring children of the group to another group.

In the crime of genocide, there are terms to understand. The meaning of "intentionally" in a formulation of crime is the requirement of specific mens rea where the perpetrator should be proven to have an intention to destroy in whole or in part one of the four protected groups. "In whole or in part" means that the perpetrator is not necessarily to have intention to destroy all the members of the group but the intention to destroy the part of the group is sufficient to be deemed committing the genocide. While "protected groups" are defined as four vulnerable groups of target of genocide: national, ethnic, racial, and religious groups.[7]

Under Article 9 of Law Number 26, 2000 , crime against humanity is one of actions committed as part of widespread or systematic attack directed against any civilian or an identifiable part of a civilian population, in the form of:

1) murder;

2) destruction;

3) enslavement;

4) deportations or forcibly transferring of population;

5) arbitrarily deprivation of independence or physical independence violating the principles of international laws;

6) torture;

7) rape; sexual slavery, enforced prostitution, forced pregnancy, enforced sterilization, or other forms of sexual violence;

8) repression against political, racial, national, ethnic, cultural, religious, gender groups or against other grounds recognized internationally as illegal;
9) forced disappearance;

10) Apartheid

Positive law stipulates that the establishment of Court of Human Rights is the mark that the violations against human are handled using due process model. It is known that Court of Human Rights is a special court established under the Law Number 26, 2000. It operates under the general court and stands in Regencial/Municipal level whose duty and power to examine and adjudicate any case of gross human rights violation committed outside the territory of Republic of Indonesia by Indonesian citizens.

The nature of due process model in handling the gross violations against human rights is the components in criminal justice system, such as:

\section{1) National Commission of Human Rights}

Under the Law Number 26, 2000 on Court of Human Rights, the National Commission of Human Rights functions as the sole institution with power to conduct investigation upon gross violation against human rights. This kind of violations includes in extraordinary crimes that cannot be resolved using the existing legal instruments stipulating ordinary crimes.

\section{2) General Attorney}

Under Article 11 of Law Number 26, 2000 cases of human rights violation, General Attorney is in power to conduct investigation to apprehend for the investigation process against persons allegedly conducting gross human rights violation based on probable cause found. Article 12 of the law stipulates that General Attorney as the investigator and prosecutor is authorized to apprehend or to hold a person in detainment for investigation and prosecution.

\section{3) Court of Human Rights}

The Court of Human Rights has duties and power to examine and adjudicate cases of gross human rights violation committed outside territory of Indonesia by Indonesian citizen. In addition, Indonesia recognizes The Human Rights Court with power to adjudicate gross violation against human rights prior the enactment of Law Number 26, 2000. Therefore, gross violation against human rights does not recognize expiry. In other 
words, Court of Human Rights adopts the principle of retroactive upon the gross violation against human rights.

As for the handling of violation against human rights, the establishment of Court of Human Rights is based on the allegation that a gross violation against human rights was taken place. The allegation is then investigated by the National Commission of Human Rights by establishing Investigation Commission of Human Rights Violation. In the case evidence is found indicating that a gross violation against human rights has occurred, the case is submitted to General Attorney for inquiry. In this stage, if the findings shows any gross violation of human rights, the case will proceed to prosecution conducted by General Attorney as well. Based on the evidence and prosecution in the arraignment, the court trial on the violation of human rights will proceed. The trial will be held in District Court of locus and tempus delictie of the violation.

Court of Human Rights stipulates the jurisdiction of the cases on gross violation against human rights pre or post the enactment of the Act. For the gross violation against human rights, upon the examination and adjudication of the case, a Court of Human Rights should be established that differs from a Human Rights Court (permanent) which is able to examine and adjudicate gross violation against human rights post enactment of the Law Number 26, 2000.

This process differs from the establishment process of the Human Rights Court that should follow some stages to meet the requirements: 1) there is an allegation of gross human rights violation based on the findings of past case investigation by the National Commission of Human Rights; 2) findings of inquiry by General Attorney; 3) recommendation from the House of Representative to the government to hold a Court of Human Rights upon certain tempus and locus delictie; 4) Presidential Decree on the establishment of ad hoc Court of Human Rights.

Of the stage of the court proceeding, it is known that the handling of gross human rights violation tends to apply the due process model in which the characteristic of adjudicative formal is still applied in the handling process by considering the rights of the perpetrator and victims.
Article 10 of Law Number 26, 2000 states that procedure law used is under the Code of Criminal Procedure Law unless regulated otherwise. There are specialty in the handling of the gross crimes against human rights stipulated in the Law Number 26, 2000:

1. Investigator is necessary by establishing ad hoc team of investigator, prosecutor, and adjudicator.

2. Explicit provision is required that investigation is solely conducted by the National Commission of Human Rights and investigator is not authorized to receive report or complaint as stated in the Code of Criminal Procedure Law.

3. Provision on certain period to conduct investigation, prosecution, and examination in the court is necessary.

4. Provision on the victim and witness protection is required.

5. Provision on no expiry for gross human rights violation is required.

This specialty is elaborated in each and every single article i.e. Article 11 to Article 33 of Law Number $26 / 2000$ as the exception to the stipulations in the Code of Criminal Procedure Law. Therefore, it can be understand the different in handling a gross violation against human rights and an ordinary violation against human rights as below:

\section{1) Investigation}

Investigation is solely conducted by the National Commission of Human Rights, no other investigator is in power to receive report or complaint. The power to investigate that is different from what stipulated in the Code of Criminal Procedure Law is the specialty in investigation of gross violation against human rights. The investigaton conducted by the Commission is a pro justitia investigation. This power is to maintain objectivity of the findings since the National Commission of Human Rights is an independent institution both institutionally and its member.

Institutionally, the National Commission of Human Rights is considered to not have interests unless in the protection and enforcement of Human Rights in Indonesia while the members of the Commission are consider to be highly integrated and technical ability to conduct an investigation. In conducting an investigation the National Commission of Human Rights forms an ad hoc team comprising of the National Commission 
of Human Rights and the community, particularly the prominent profiles of the community who are professional, dedicated, with high integrity, and master the human rights issues.

\section{2) Inquiry}

Party authorized to conduct investigation of gross violation of human rights is General Attorney. This investigation excludes to receive complaints and reports since these are included in the power of the National Commission of Human Rights. In carrying out the investigation, General Attorney may appoint ad hoc investigator from the community and government. Ad hoc prosecutor is prioritizedly taken from exprosecutor of General Court or military prosecutor of Military Court.

\section{3) Prosecution}

Prosecution of gross violation against human rights by General Attorney and in the prosecution, General Attorney may appoint ad hoc prosecutor comprising of government and or community. Ad hoc prosecutor from the community is taken from ex-prosecutor in General Court or military prosecutor in Military Court.

\section{4) Court Trial}

In a trial of gross violation against human rights, presiding judges consisting of 5 (five) persons comprises of 2 (two) judges at the given Court of Human Rights and 3 (three) ad hoc judges. These presiding judges are lead by a judge from given Court of Human Rights. The appointment and dismissal of ad hoc judges is in the hand of the President as the head of the state upon recommendation of Chief Judge of The Supreme Court. Ad hoc judge is defined as a judge appointed among career judges who is professional, dedicated, with high integrity, and master the issues of the goal of a law state and welfare state upholding justice, understand and respect the human rights and the basic duties of human.

At the appallate level, presiding judges consist of 5 (five) judges: 2 (two) judges of Appallate Court given and 3 (three) ad hoc judges. While at the cassation level, the presiding judges are 5 (five) consisting of 2 (two) judges of Supreme Court judges and 3 (three) ad hoc judges. Differ from the appointment of judges at the Court of Human Rights and Court of Appeal, at the cassation level, ad hoc judges are appointed by the President as the head of the state upon recommendation of the House of Representatives. Judicial review in which the application at the appallate and cassation stage is limited by time.

From the above mentioned, the handling process of human rights violation is still weak resulting in juridical handicaps in the implementation. The weaknesses are:

\section{In Material Law}

There is no integration of the handling of minor human rights violation and the gross violation. Therefore, in handling the violation against human rights, it is necessary to analyze which regulation is violated before considering whether a violation occurs using justice system that is different one another.

It certainly inflicts dilemma in the component of law enforcement particularly National Commission of Human Rights established to be responsible of the monitoring and the protection of Human Rights in Indonesia. The National Commission of Human Rights reported that many violations were not followed up by the law enforcement.

The absence of unifying criminal justice system in addressing the violation against human rights leads to ineffectiveness in the law enforcement. Accordingly, the weakness of material law in handling this violation in Indonesia should be overcome considering the implementation of ineffective existing laws.

In addressing the violation of human rights, particularly a gross violation, there are weaknesses in material law i.e. in Law Number 26, 2000 regarding the inaccuracy in terminology used, misinterpretation and narrow jurisdiction of the court.

\section{Weakness in Formal Law}

With the separated laws in handling human rights violation, it certainly inflicts problems in formal laws. In this case, the National Commission of Human Rights as the institution collecting every complaints reported with authority to investigate faces limitation to follow up the violations so that the reports are filed up at the Commission with no follow ups. This is due to unclear procedure especially the procedure in handling minor human rights violation.

The handling of gross violations against human rights as stipulated in Law Number 26, 2000 some problems raised:

a. Unclear explanation on probable cause 
b. The absence of the power of investigator to do forced action.

c. The relation of the investigator and inquirer such as: 1) the absence of date line for the investigator to report the findings back; 2) the absence of the laws on time limit to commence an investigation. 3) The absence of laws regulating the dispute settlement between investigator and inquirer.

d. Time limit to prosecute is too short

e. The absence of the regulation on procedure to propose the establishment of ad hoc Court of Human Rights.

f. The weakness on victims and witness protection system.

g. The weakness on the compensation, restitution and rehabilitation system.

h. Pledge of the Investigator

i. Sumpah Bagi Penyelidik

j. Death Penalty still in force

Of the weakness on the implementation of the handling of human rights violation in Indonesian criminal justice system, Indonesia, as the state law, should act quickly to make a reformed concept of the handling of human rights violation through various policies in criminal law so that the future law enforcement can run more effectively to achieve the goals in law making by stressing on the proper and appropriate justice values.

\section{A. Handling Concept of Violation against}

Human Rights under the Justice Principle through Criminal Justice System in Indonesia

In the literature, crime against human rights is categorized as an extraordinary crime with the formulation and causal factors different from ordinary crimes.

As for the gross violation against human rights, it is called extraordinary crimes since the crime is so cruel and inhumane that deeply shocks that conscience of humanity and is a threat to international peace and security. Moreover, if it is committed in a "systematic or widespread and flagrant [8]. By formulating that any crimes against human rights are extraordinary crimes, it is impossible to uniform the treatment to resolve the problems.

This view certainly produces a notion on the form of specific handling applying special mechanism in the process. General criminal law often cannot bring the perpetrator of the crime against human rights to justice effectively. Therefore, the Law Number 26, 2000 was enacted. In revising the Law Number 26, 2000, the philosophical based and guidance in the nation and state i.e. Pancasila cannot be separated.[4] In addition to the philosophical foundation, Pancasila is the source of legal source under which the law is given soul, percepted, and elaborated. The elaboration of the values of Pancasila in the provisions and amendment should reflect the values of humanity, justice, order, and welfare as the idea of Indonesian people. The values contained in Pancasila will guarantee the legal resolutions that is fair, impartial, independen and respectful to the principles of human rights in all conditions whatsoever in particular in the situation where crimes against the protection of man and human dignity are easy to occur.

The state power to form the structure of norms related to the protection of human rights for its citizens (individual). It is because human rights is the rights attached to man due to their nature and power since they were born. These nature and power should be guaranteed by the state. It is "attached" or "inherent" because those rights are owned by anybody and cannot be taken away or unrooted. On this ground that the human rights regime comes as part of the implementation of social contract theory.

General principle on equality before the law encourage any individual or party committing a crime against legal norm to bear the consequence of the action, to be responsible either individually or collectively. The mechanism of the gross human rights violation requires special treatment. It is not in a sense of discrimination in handling the case nor of discrimination against the perpetrator. The characteristic of specific Human Rights violation requires a special court that is able to uphold justice for each party.

Under Article 1 point 6 of Law Number 39,1999 , it is stated that any crimes of human rights should be resolved through mechanism of applied law.[1] Nature Law (Naturerech School) argued that state is the representation of man's or individual's will. Therefore, it is the state responsibility to channel the community's will that gives the state's rights to ask the responsibility of perpetrator of a crime (ius punale) and to criminally sanction if the deed is proven guilty (ius puniendi). This 
method, then, is the justification for the state to carry out the law mechanism applied.

R. B. Brandt argued that Human Rights as legal rights can be defined as institutional mechanism in which the interest of an individual is guaranteed by law. Each effect of individual choice is assured by law as well or that the goods or opportunity given to the individual is under the applied law. Therefore, law is crucial to be the parameter of true or false by referring to applied regulations. Ini this context, Bentham argued how stands the truth of things? That there are such things as natural rights-no such things as rights anterior to the establishment of goverment - no such things as natural rights opposed to, in contradiction to, legal: that the expression in merely figurative; that when used, in the moment you attempt to give it a liberal meaning it leads to error and to that sort of error that leads to mischief, to extremity of mischief [9]

Policy of criminal law concerning the handling of human rights in Indonesia for the category of gross human rights of violation is stipulated under the Law Number 26, 2000 while for the category of minor violation of human rights is adjusted to the provisions on the offenses that indirectly against the classification of rights included in minor category of human rights violation.

The criminal law policy in addressing the issue of human rights violation recently applied is deemed ineffective and not served the sense of justice in the society. It is due to the incomprehensive handling system of human rights violation applied.

Unfairness in the handling of the violation against human rights from year to year is excalating. Many reports and complaint received by the National Commission of Human Rights on day to day basis are piled up and sometimes no follows up for years. It shows that the applied system is not so optimum that no satisfaction for people in maintaining and fighting for their rights with the law enforcement, in this case the National Commission of Human Rights. Accordingly, justice in obtaining equality before the law is not reflected in Indonesia leading dissatisfaction towards the law enforcement today.

Hans Kelsen argued that law as the social structure to be deemed justiced is if it can guide the human conduct through a satisfying means for man to find happiness.[10] The center of the justice in the law enforcement as proposed by Hans Kelsen is happiness. Certainly, by looking at the philosophy adopt by Indonesia, Pancasila, the justice fits with the condition in Indonesia with diversity is the one reflecting the Indonesia.

As understood, justice in Pancasila is reflected in fifth sila (moral principle) saying "social justice for entire people of Indoneisa". Soediman Kartohadiprodjo proposed that the term "social" is defined as the inter-individual relation in given group. Each individual holds four elements or components of life which are corporal body, sense, and ratio and to live in harmony. These four should be well retained to obtain peacefulness, balance, and harmony.[11] Hence, the expected happiness as illustrated in the fifth sila of Pancasila is the same with "social justice" or "social welfare".

That the handling of human rights violation in Indonesia is not uniformly regulated materially nor formally. Therefore, for the concept of the handling of human rights violation in the criminal justice system to be effective according to the objectives of the promulgation of a policy in criminal law i.e. to produce a good law that meets the requirements of justice and practical, an integrated criminal justice system is necessary.

Muladi viewed that the meaning of this integrated justice system is the synchronization or uniformity and harmony that differs in: first, structural synchronization that is a uniformity and harmony in the frame of inter-institutional relation of law enforcement; second, substantial synchronization that is vertical and horizontal uniformity and harmony in the relation to the positive law; third, cultural synchronization i.e. uniformity and harmony in comprehending the views, acts, and philosophy underlaying the criminal justice system.[8]

The term integrated in criminal justice system is the similarity in procedure (subsystem) in criminal justice where each post should comply with the provisions set up/applied), perception (equal undertandings/knowledge within the subsystems regarding the cases handled) and the objectives (justice sub-systems should have the same objectives to eradicate crimes up to the limit of tolerance acceptable by 
people)[12] By applying concept of integrated criminal justice system as part of the theory on criminal justice system, the objectives of the criminal justice system in handling the human rights violation in Indonesia can be realized as such:

a) Prevention of victim of crime;

b) Resolution to the crime occurred to satisfy people that justice has been served while the guilty one is punished;

c) Prevention of crime relapsed.

Of the weaknesses in handling the crimes against human rights stipulated in the Code of Criminal Procedure and the Law Number 26, 2000, the concept of the eradication of the violation against human rights for future application is by conducting structural synchronization, substantial synchronization, and cultural synchronization.

Structural synchronization is the harmony in the frame of inter-institutional relation of law enforcement. As for the relation with the handling of human rights violation is that three components of criminal justice system (National Commission of Human Rights, Judicial Court and Correctional Service) are expected to be able to cooperate and to form an integrated criminal justice system. This is to realize the principle of responsive, simple, and affordable court. Therefore, it does not require long period of time due to the complicated and high cost process to reveal a case of human rights violation.

Substantial synchronization i.e. vertical and horizontal uniformity and harmony in the relation with the positive law. With the weaknesses in the substance of the law on the handling of human rights violation both material and formal in Indonesian positive laws, it is important to make some changes or reformation on the legal policy.

Objectives of law (especially in the relation to criminal law) naturally has two components:

a. As the facility to form norms;

In the development of the community where the paradigm on new norms regulating the social relation in the society is important.

b. As the facility to strengthen norms;

It is when norms exist and the living law in the community but are not reflected in the written laws. It is then promulgated as positive law and strengthened as written law.

As the instrumental media i.e. instrument for the law enforcement especially in the criminal law and as the means to limit the power as well. In achieving the objectives, the discussion on the principle is vital regarding the application of the principle of general criminal law that might not be suitable and incompatible with the kinds of crimes against human rights that naturally has specific characteristic not only related to the material but also to formal law.

As the form of a new concept in the handling of human rights violation under the principle of justice through criminal justice system in Indonesia, there are major subsystem need to apply that is the power integration of pre-adjudiation process in the human rights court (investigation, inquiry, and prosecution) into the National Commission of Human Rights.

The findings showed that the separation of power of investigation, inquiry, and prosecution indicate a weakness in the judicial process to handle cases of crimes against human rights. Some weaknesses are"

a. Inter-institution coordination between the National Commission of Human Rights as the intevestigator and General Attorney in inquiry and prosecution;

b. Different interpretation between two institutions in examining whether probable cause exists;

c. The National Commission of Human Rights, the sole institution with power to forcedly sub poena deemed to have legal consequence if waived/ignored and obstruct the justice process.

The ground to produce thought of the need to unify the two institutions. Some options are:

a. Extent the power of National Commission of Human Rights in investigation, inquiry, and prosecution; or

b. Establish an independent institution to investigate and inquire.

Institutionally, option B is considered to bring large consequence because it is not easy to establish a new institution. In addition, it will needs new infrastructures and facilities that certainly will be on the expenses of the state. 
As to assign the option $\mathrm{A}$ to the Commission, basically will help to speed the process since the Commission is considered as an independent institution mastering the issue of human rights theoretically and practically. Assigning the power to the Commission would include it into the criminal justice system and automatically would make it a state organ. The standing of the commission as an independen organ would be under scrutiny since acting as investigator and inquirer, the commission is undergoing the state power meaning that it becomes the representatives of the government. In this position, the commission would no longer independent. Paris principles only highlights the independence of the institution such as the National Commission of Human Rights with function to monitor the implementation of human rights in Indonesia and may report the findings to the international mechanism of human rights. Even though the extention of the power of the commission, financially, would be additional expenses for the state in completing the facilities and infrastructures necessary for the investigation and for the expenses when handling the case deemed to be very limited.

The changes in the handling of the gross crimes against human rights will positively inflict the aspects of society. At the justice aspect, people especially the victims at national, regional, and international level would have a clear vision on the sense of justice served. At the institutional aspect, especially among institutions with correlation in the handling of the crimes against humanity, such as the National Commission of Human Rights, General Attorney, and judicial courts would get an assurance in following up the case. In addition, the application of a new system to be regulated would give an opportunity for the people to participate directly in the handling of the crimes against human rights.

As for the law enforcement, consistency of the action taken by state organ defines the level of legal assurance achieved. It means that in the implementation of power assigned to the enforcement of human rights, the consistency of the application of the law sets the bar of the upholding the legal assurance. Therefore, it is necessary to enact one particular regulation assigning power of each institution and the inter-authority relation would run to one particular direction of procedural system of human court that is fair and qualified.

\section{Conclusion}

a. The handling of human rights violation in the perspective of criminal justice system in Indonesia applies due process model. It is evidenced with the existence of institution handling the crimes categorized as minor human rights violation at General Court while for category of gross violation against human rights, the case handled specifically through Human Rights Court as stipulated in the Law Number 26, 2000 concerning Court of Human Rights. Directing towards the due process model because the judicial process is carried out through adjudicative formal method by by respecting the presumption of innocence principle in the whole process of investigation, inquiry, prosecution, and court examination. The implementation of the handling of human rights violation through criminal court in Indonesia, so far still faces obstacles especially with the weaknesses in material law of which no integration of regulation on the handling of minor violation of human rights and of the gross violation. This led to overlapping of the power inter-components of law enforcement in particular of the National Commission of Human Rights as the institution established to be responsible for monitoring and protecting the human rights in Indonesia. As for the weakness in formal law is that the National Commission on Human Rights, as the institution collects every reports on human rights violation, holds power only in investigation. Certainly, it faces limited access to follow up violations of human rights occurred therefore many data on the violations are piled up with no follow ups due to unclear procedure especially in the handling of minor violations against human rights.

b. Concept of the handling of human rights violation is under principle of justice through criminal justice system in Indonesia conducted through intergrated criminal justice system. To have an integrated criminal justice system, one of the measures is to assign full power to the National Commission of Human Rights in 
handling cases of human rights violations on stage of investigation, inquiry and prosecution. It is due to the separation of power in investigation, inquiry, and prosecution which is considered as one of weaknesses in the implementation of justice process of human rights violations.

\section{BIBLIOGRAPHY}

[1] R. Indonesia, "Undang-Undang Nomor 39 Tahun 1999 tentang Hak Asasi Manusia," 2012.

[2] Sigit Riyanto, "Penegakkan HAM Di Indonesia Beberapa Catatan Kritis," Maj. Mimb. Huk. No.38/VI/2001 FH$U G M$, vol. 38, 2001.

[3] Bagir Manan, "Perkembangan Pemikiran dan Pengaturan Hak Asasi Manusia di Indonesia," 2001. .

[4] H. A. Manusia, Bahwa Hak Asasi Manusia Merupakan Hak Dasar Yang Secara Kodrati Melekat Pada Diri Manusia, Bersifat Universal Dan Langgeng, Oleh Karena Itu Harus Dilindungi, Dihormati, Dipertahankan, Dan Tidak Boleh Diabaikan, Dikurangi, Atau Dirampas Oleh Siapapun; 2000.

[5] Yahya Harahap, Pembahasan Permasalahan Dan Penerapan KUHAP: Penyidikan dan

Penuntutan, Edisi. 2.,. Jakarta: sinar grafika, 2003.

[6] Marwan Effendy., Sistem peradilan pidana : tinjauan terhadap beberapa perkembangan hukum pidana, Cetakan . Jakarta: Jakarta : Referensi, 2012., 2012.

[7] U. Nations and G. Assembly, "United nations convention on the prevention and punishment of the crime of genocide," Int. J. Hum. Rights, vol. 4, no. 3-4, pp. 336-340, 2000.

[8] Muladi, Kapita selekta sistem peradilan pidana. semarang: Badan Penerbit, Universitas Diponegoro, 1995.

[9] Hugo Adam Bedau, “Anarchical Fallacies: Bentham's Attack on Human Rights," Hum. Rights Q., vol. 22, no. Human Rights.

[10] hans kelsen, General Theory of law \& state. new runswick (USA) and london (UK): harvard university press, 2011.

[11] Soediman Kartohadiprodjo, Pancasila sebagai Pandangan Hidup Bangsa Indonesia, . Jakarta: Gatra Pustaka, 2010.

[12] Rusli Muhammad, Sistem peradilan Pidana Indonesia. Yogyakarta: UII Press, 2011. 